\title{
An Investigation of the Critical Success Factors of IT Projects in Saudi Arabian Public Organizations
}

\author{
Abdulaziz I. Almajed and Pam Mayhew \\ School of Computing Sciences, UEA, Norwich, UK \\ Correspondence should be addressed to: Abdulaziz I. Almajed; a.almajed@uea.ac.uk \\ Received 31 August 2012; Accepted 22 May 2013; Published 23 October 2013 \\ Academic Editor: Lau Siong Hoe \\ Copyright (C 2013 Abdulaziz I. Almajed and Pam Mayhew. Distributed under Creative Commons CC- \\ BY 3.0

\begin{abstract}
Despite of the huge investments in information technology (IT), IT project success rates are unsatisfactory and still remain very low. This issue has been investigated by many researchers all over the world to identify the critical success factors. However, there is no universal agreement on which factors are significant to success. This paper presents an investigative study of the main factors that affect IT projects success in Saudi Arabian public organizations. A two-phase approach has been adopted combining qualitative and quantitative research methods. In phase I, a qualitative approach using semi-structured interview method was used to collect and analyze the data, and the findings of this phase proposed seventeen factors. Then, in phase II, a quantitative approach using questionnaire method was used to assess and validate the outcomes of phase I. The findings of the questionnaire confirmed the importance of those seventeen factors, and the critical success factors (CSFs) of IT projects in Saudi Arabian public organizations to be found are: top management support and commitment, project management, project team competency, communication management, strategic planning, training and education, partners and suppliers management, and stakeholders management.
\end{abstract}

Keywords: IT project, CSF, public, Saudi.

\section{Introduction}

Information technology (IT) is the backbone of any business where it would be impossible to function without it. In order to enable organizations to stay competitive, attention to the issues related to successful projects has been tracked by academics and practitioners. With the expectation to make a significant contribution to the organization's efficiency, effectiveness, and competitive positioning, there are many indications that organizations are spending enormous amounts of money investing in IT. However, IT project failures rates are still high in spite of the huge investments in IT. Many IT projects have been categorized as failures in developing countries, "Alongside the successes many information systems in developing countries can be categorized as failing either totally or partially" (Heeks, 2002). The rise in IT projects failure is a result of the increasing organizational impact of information technology. 
In developing countries, IT researchers still have interest in the area of IT project success (Chevers and Duggan, 2012). Even though there is an intensifying theoretical and empirical studies on IT project failures, most of the CSFs studies are derived from developed countries and from the private sector (Gauld, 2007), and limited attention has been made toward the IT success in public sector (Hussein et al., 2007). In highincome developing countries, there has not been much research on the project CSFs even though they have a vast potential market for IT projects; so more researches should be directed to these regions (Ngai et al., 2008). With respect to Saudi Arabia, trivial attempts have been made to identify and investigate the factors that are responsible for IT projects failure (Alghobiri, 2003). Therefore, the aim of this research is to identify the CSFs factors that affect the success of IT projects in Saudi Arabian public organizations.

This study contributed to existing knowledge in different ways. First, it managed to identify the CSFs of IT projects success in high-income developing countries in general and in Saudi Arabia in particular. Second, this study succeeded in synthesizing existing literature in this area with its findings from real world experience. The paper is organized as follow: section 2 presents a literature review and section 3 presents phase I (exploratory study) methodology and findings. Sections 4 and 5 describe phase II (validation study) methodology and survey findings. The last section provides the conclusion and further research.

\section{Literature Review}

Several research studies have been done in the CSFs that effect the project success/failure (Pinto and Mantel Jr, 1990; Belassi and Tukel, 1996; Tukel and Rom, 2001; White and Fortune, 2002). However, most of the CSFs studies concentrate on specific IT projects (e.g. ERP). In highincome developing countries such as Saudi Arabia, few studies have been done to identify the CSFs in ERP, Portal and Health Information System (HIS). The following will brief the findings of these studies.

Al-Mashari and Al-Mudimigh (2003) found in their case study of a failed ERP implementation for a major middle-eastern manufacturer (Comp Group) that the critical failure factors (CFFs) are: scope creep, lack of ownership and transfer of knowledge, lack of change management, lack of communications, lack of performance measurement, and propensity to isolate IT from business affairs. Al-Turki (2011) found in his study on the ERP implementation practices that management commitment, the existence of a clear strategic objective, change management, and training were critical for the success of the ERP implementation. Abouzahra (2011) found in his study of 52 HIS projects that the main factors behind healthcare IT project failure are unclear scope, failure to manage risks, failure to identify stakeholders, and miscommunications. Al-Mudimigh et al. (2011) found in their two case studies of portal implementation that the top five factors affecting the success are organizational which are good communication, user acceptance, top management support, clear goals and objectives, and project monitoring and controlling. From the literature, it was found that a number of factors affect IT project success in all types of organizations, Table 1 summarizes the findings. 
Table 1: Success Factors Identified in Literature

\begin{tabular}{|c|c|}
\hline Success Factors & Literature \\
\hline $\begin{array}{l}\text { Top Management } \\
\text { Support and Commitment }\end{array}$ & $\begin{array}{l}\text { (Fortune and White, 2006; Jiang et al., 1996; Holland and Light, } \\
\text { 1999; Shanks et al., 2000; Young and Jordan, 2008; Al-Mudimigh } \\
\text { et al., 2011; Dezdar and Ainin, 2012) }\end{array}$ \\
\hline Strategic Planning & (Gunasekaran and Garets, 2003; Hong, 2009; Al-Turki, 2011) \\
\hline Project Management & $\begin{array}{l}\text { (Ross, 1999; Holland and Light, 1999; Rosario, 2000; Murray and } \\
\text { Coffin, 2001; Sumner, 1999; PMI, 2004; Dezdar and Ainin, 2012; } \\
\text { Nah et al., 2007) }\end{array}$ \\
\hline Process Management & $\begin{array}{l}\text { (Anderson and Rungtusanatham, 1994; Benner and Tushman, } \\
\text { 2002; EFQM-MultiProject, 2010; Al-Mudimigh, 2007) }\end{array}$ \\
\hline $\begin{array}{l}\text { Project } \\
\text { Competency }\end{array}$ & $\begin{array}{l}\text { (Shanks et al., 2000; Ross, 1999; Holland and Light, 1999; } \\
\text { Sumner, 1999; Jiang et al., 1996; Alghathbar, 2008; Dezdar and } \\
\text { Ainin, 2012) }\end{array}$ \\
\hline IT Readiness & $\begin{array}{l}\text { (Somers and Nelson, 2004; Kumar et al., 2002; Gupta, 2000; Al- } \\
\text { Mudimigh, 2007) }\end{array}$ \\
\hline Change Management & $\begin{array}{l}\text { (Bhatti, 2005; Somers and Nelson, 2004; Gupta, 2000; Esteves } \\
\text { and Pastor, 2001; Al-Shamlan and Al-Mudimigh, 2011) }\end{array}$ \\
\hline Risk Management & $\begin{array}{l}\text { (Baccarini et al., 2004; PMI, 2004; Kemppainen et al., 2012; Al- } \\
\text { Mudimigh et al., 2001) }\end{array}$ \\
\hline $\begin{array}{l}\text { Communication } \\
\text { Management }\end{array}$ & $\begin{array}{l}\text { (Ross, 1999; Rosario, 2000; Jiang et al., 1996; Holland and Light, } \\
\text { 1999; Sumner, 1999; Al-Mashari and Al-Mudimigh, 2003; Dezdar } \\
\text { and Ainin, 2012; Nah et al., 2007) }\end{array}$ \\
\hline Training and Education & $\begin{array}{l}\text { (Finney and Corbett, 2007; Kumar et al., 2002; Robey et al., 2002; } \\
\text { Mandal and Gunasekaran, 2003; Aladwani, 2001) }\end{array}$ \\
\hline $\begin{array}{l}\text { Partners and Suppliers } \\
\text { Management }\end{array}$ & (Zhang et al., 2003; Kansal, 2007; ISO9000, 2000; AlShitri, 2008) \\
\hline $\begin{array}{l}\text { Stakeholders } \\
\text { Management }\end{array}$ & $\begin{array}{l}\text { (Shenhar and Dvir, 1996; Crawford, 2005; Morris et al., 2006; } \\
\text { Bourne and Walker, 2008; PMI, 2004; Abouzahra, 2011) }\end{array}$ \\
\hline
\end{tabular}

Phase I (Exploratory Study) - $\quad \begin{aligned} & \text { enable full discussion of the topics } \\ & \text { included. }\end{aligned}$
Methodology and Findings

Phase I of this study empirically explores the factors that play a significant role in the success of IT project in Saudi Arabian public organizations. In order to identify these factors, a qualitative method using semi-structured interview is used. This exploratory study carried out through interviewing a number (10) of chief information officres (CIOs) using a list of factors which has been collected from the literature review. The semi-structure interview process went through the following steps. First, the researchers proposed a list of factors from a thorough review of the literature on the success factors of IT projects to be examined and modified by the interviewees. For the interview to succeed and to save the CIO's valuable time, the researchers had emailed this list to them in advance in order to
Invitations were sent to 20 CIOs in the field, and only 10 agreed to participate in this study. Only those who had at least five years' experience of IT management were chosen, and the reason for that was to consult people with significant levels of practical experience. The researchers conducted interviews during October 2012. Each interviewee was briefed on the information concerning the aims of the study and the purpose of the interviews. The duration of each interview was one hour, and each interview was conducted on a one-to-one basis. Participating CIOs were assured of their anonymity before the beginning of each interview. The researchers conducted the interviews using the voice over IP (Skype). None of the interviews were tape-recorded because the CIOs requested that information they 
provided not to be recorded. Therefore, notes were taken. These interview notes were emailed to each CIO after the interview for confirmation and validation.

After the interview process with the CIOs had finished, the researchers started to analyze the interviewees' answers. The researchers transcribed the results in a separate form for each interviewee. This form consists of the following: CIO's background, organizational and IT characteristics, a list of factors from the literature to be confirmed if it is important or not, and a space for any additional factors that can be added. In the data transcribing process, the researchers marked (囚) when the CIO confirmed the importance of one of the factors that were listed in the interview results form. If, however, the interviewee suggested a new factor, the researchers added it to the proper space in that form. The researchers also wrote down the interviewees' comments about each factor. After this, the process of transcribing the interview results was finished, and the data analysis process started in order to identify the factors which have influence on IT project success.

The findings of this study proposed seventeen factors that may have effect on IT projects success. Conflict of interest, knowledge management, rewards and recognition, top management stability, and project management office (PMO) have been collected from the interviewees. Top management support and commitment, strategic planning, project management, process management, project team competency, IT infrastructure, change management, risk management, communication management, training and education, supplier management, stakeholder management have been collected from the literature and confirmed by the interviewees (Almajed and Mayhew, 2013).

\section{Phase II (Validation Study) - Methodology}

Phase II of this study empirically validates the seventeen success factors of IT projects that had been found in phase I and identifies the critical ones in Saudi Arabian public organizations. Therefore, in order to achieve this goal, a quantitative method using questionnaire was used, and data analysis consisted of descriptive statistics and frequency distributions were used. The list of CSFs has been prepared in order of their importance using statistical mean ranking, and scores with a mean item response of 4 or higher considered as critical factor. Moreover, the target of this study was IT professionals, consultants, and CIOs in Saudi Arabia.

The questionnaire consisted of two sections. In section 1 , the respondents were required to fill their demographic profile such as gender, age, position, and experience. Section 2 requires the respondents to indicate their perceptions on the factors that influence IT projects success using a five-point Likert-type scale with anchors ranging from "strongly agree" to "strongly disagree". Having designed the survey form, the questionnaire was sent to a group of IT professionals, consultants, and CIOs for validating and piloting the instrument. Only those who had at least six years' experience of IT management were chosen. The reason for that was to consult people with significant levels of practical experience. Based on their responses and in order to improve the clarity of the instrument, certain adjustments were incorporated into the final version of the questionnaire such as the wording and the statement clarity of each item. Then, the content validity of the instrument was thereby addressed.

The improved questionnaires, together with a covering letter explaining the purpose of the survey/study, were emailed to the target people. Invitations have been sent to 75 experts directly or indirectly using email and LinkedIn social network in order to maximize the response rate. The distribution took place during January 2013. A total of 41 questionnaires were returned, of which 2 were spoilt leaving 39 for the analysis (a response rate of 52\%). The high response rate could be attributed to both the level of interest in the subject or the direct and personal/email approach 
used by the researchers. Although this personal approach was time-intensive and costly, and can be impractical in some cases, it proved effective for this study. Following the data collection the responses were coded to enable them to be computer processed. The software package used for the analysis was SPSS 18.0 (statistical package for the social sciences) for Windows.

\section{Survey Findings and Discussion}

Table 2 presents the characteristics of respondents. As can be seen, there were more Saudi respondents and most of them were male. Also, most of the respondents were above 30 years old, and held university degree (Bachelor /Master). Two thirds of the respondents were CIO/Director/Manager and most of them had more than 6 years of experiences.

Table 2: Characteristics of the Respondents

\begin{tabular}{|c|c|c|c|c|}
\hline Measure & Categories & Frequency & Percent & $\begin{array}{l}\text { Cumulative } \\
\text { Percent }\end{array}$ \\
\hline \multirow{2}{*}{ Nationality } & Saudi & 31 & 79.5 & 79.5 \\
\hline & Non-Saudi & 8 & 20.5 & 100.0 \\
\hline \multirow{2}{*}{ Gender } & Male & 38 & 97.4 & 97.4 \\
\hline & Female & 1 & 2.6 & 100.0 \\
\hline \multirow{5}{*}{ Age } & $<26$ & 1 & 2.6 & 2.6 \\
\hline & $26-30$ & 1 & 2.6 & 5.2 \\
\hline & $31-35$ & 10 & 25.6 & 30.8 \\
\hline & $36-40$ & 11 & 28.2 & 59 \\
\hline & $>40$ & 16 & 41.0 & 100.0 \\
\hline \multirow{4}{*}{$\begin{array}{l}\text { Last } \\
\text { Educational } \\
\text { Qualification }\end{array}$} & Below Bachelor & 2 & 5.1 & 5.1 \\
\hline & Bachelor & 10 & 25.6 & 30.7 \\
\hline & Master & 23 & 59.0 & 89.7 \\
\hline & PhD & 4 & 10.3 & 100.0 \\
\hline \multirow{3}{*}{ Field of Study } & Computing & 28 & 71.8 & 71.8 \\
\hline & Engineering & 3 & 7.7 & 79.5 \\
\hline & Management & 8 & 20.5 & 100.0 \\
\hline \multirow{3}{*}{ Position } & $\begin{array}{l}\text { CIO / IT Director / IT } \\
\text { Manager }\end{array}$ & 26 & 66.7 & 66.7 \\
\hline & IT Consultant & 6 & 15.4 & 82.1 \\
\hline & IT Professional & 7 & 17.9 & 100.0 \\
\hline \multirow{4}{*}{ Experience } & $6-10$ & 8 & 20.5 & 20.5 \\
\hline & 11-15 & 12 & 30.8 & 51.3 \\
\hline & $16-20$ & 12 & 30.8 & 82.1 \\
\hline & $>20$ & 7 & 17.9 & 100.0 \\
\hline
\end{tabular}

Based on the research results that we have got from the surveys, we summarize and sort all factors that effect on IT projects success according to the means in Table 3. The results show that eight factors have means above 4 which is considered as the critical factors for IT projects to be successful. Those factors are: top management support and commitment (4.79), project management (4.54), project team competency (4.36), communication management (4.36), strategic planning (4.36), training and education (4.31), partners and suppliers management (4.18), and stakeholder management (4.15). 
Table 3: IT Project Success Factor in Saudi Arabia

\begin{tabular}{|l|l|l|}
\hline No. & IT Project Success Factor & Mean \\
\hline 1 & Top Management Support and Commitment & 4.79 \\
\hline 2 & Project Management & 4.54 \\
\hline 3 & Project Team Competency & 4.36 \\
\hline 4 & Communication Management & 4.36 \\
\hline 5 & Strategic Planning & 4.36 \\
\hline 6 & Training and Education & 4.31 \\
\hline 7 & Partners and Suppliers Management & 4.18 \\
\hline 8 & Stakeholders Management & 4.15 \\
\hline 9 & Change Management & 3.69 \\
\hline 10 & Process Management & 3.64 \\
\hline 11 & IT Readiness & 3.64 \\
\hline 12 & Conflict of Interest & 3.64 \\
\hline 13 & Rewards and Recognition & 3.49 \\
\hline 14 & Project Management Office (PMO) & 3.46 \\
\hline 15 & Risk Management & 3.33 \\
\hline 16 & Knowledge Management & 3.33 \\
\hline 17 & Top Management Stability & 3.21 \\
\hline
\end{tabular}

The overall outcomes of this study are mostly consistent with the literature review (see table 1). However, a ranking comparison of this study with Nah et al.'s (2003) study (1) of ERP success factors and Jiang et al.'s (1996) study (2) of IS implementation success factors show an interesting results (see Table 4). First of all, top management support and commitment was ranked as the top of the list in this study and study (1) while it was ranked third in study (2). Project management was ranked the second in this study and third in study (1). Project team competency was ranked third in this study and study (1) while it was ranked fourth in study (2). Finally, communication management was ranked fourth in this study and sixth in studies $(1,2)$. The other four factors of this study were not applicable for ranking comparisons since they were not included in the other studies $(1,2)$.

Table 4: CSFs Ranking Comparisons

\begin{tabular}{|l|l|l|l|}
\hline Rank & This Study & Nah et al. & Jiang et al. \\
\hline 1 & $\begin{array}{l}\text { Top Management Support } \\
\text { and Commitment }\end{array}$ & $\begin{array}{l}\text { Top Management } \\
\text { Support }\end{array}$ & - \\
\hline 2 & Project Management & - & - \\
\hline 3 & Project Team Competency & $\begin{array}{l}\text { Project } \\
\text { Competency }\end{array}$ & $\begin{array}{l}\text { Top } \\
\text { Support }\end{array}$ \\
\hline 4 & $\begin{array}{l}\text { Communication } \\
\text { Management }\end{array}$ & - & $\begin{array}{l}\text { Project } \\
\text { Competency }\end{array}$ \\
\hline 5 & Strategic Planning & Project Management & - \\
\hline 6 & Training and Education & $\begin{array}{l}\text { Communication } \\
\text { Management }\end{array}$ & $\begin{array}{l}\text { Communication } \\
\text { Management }\end{array}$ \\
\hline 7 & $\begin{array}{l}\text { Partners and Suppliers } \\
\text { Management }\end{array}$ & - & - \\
\hline 8 & Stakeholders Management & - & - \\
\hline
\end{tabular}

Based on the previous discussion, researchers were able to construct a conceptual framework (see Figure 1) of IT projects CSFs that need to be considered to minimize the failure rate of IT projects using the following propositions: 
P1: Top management support and Commitment increases the level of IT projects success.

P2: Strategic planning increases the level of IT projects success.

P3: Project management increases the level of IT projects success.

P4: Project team competency increases the level of IT projects success.
P5: Communication management increases the level of IT projects success.

P6: Training and education increases the level of IT projects success.

P7: Partners and suppliers management increases the level of IT projects success.

P8: Stakeholders management increases the level of IT projects success.

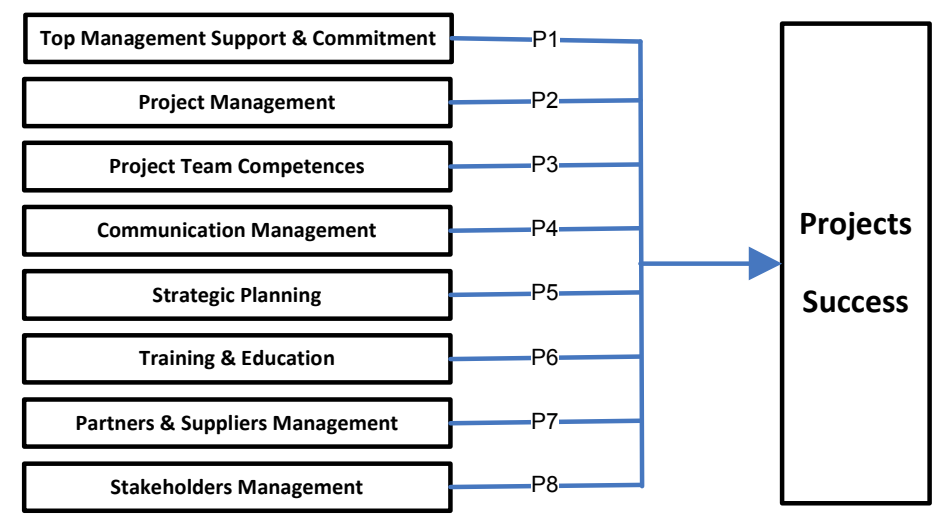

Figure 1: Conceptual Framework

\section{Conclusion and Further Research}

This paper has presented an empirical study of IT projects success factors in Saudi Arabian public organizations. The findings of the study proposed eight factors as the CSFs of IT projects success in the Saudi Arabian context. These are: top management support and commitment, project management, project team competency, communication management, strategic planning, training and education, partners and suppliers management and stakeholders management.

The success factors of IT projects found by this research are also expected to be applicable to other high-income developing countries. An enhancement framework will be presented and tested in the fourth coming paper. Further research can be done to find the interrelationships between those factors and their impact on IT project success.

\section{References}

Abouzahra, M. (2011). Causes of Failure in Healthcare IT Projects, 3rd International Conference on Advanced Management Science, 19.

Aladwani, A. M. (2001). "Change Management Strategies for Successful ERP Implementation," Business Process Management Journal, 7, 266-275

Alghathbar, K. (2008). "Practical ERP Implementation in Government Organization," International Conference on E-Learning, E-Business, Enterprise Information Systems, and E-Government, 343-349.

Alghobiri, M. A. (2003). IS Implementation and the Role of Senior Executives in Its Processes in Saudi Arabian Organisations, Doctoral, University of East Anglia 
Almajed, A. \& Mayhew, P. (2013). 'Chief Information Officers' Perceptions of It Projects Success Factors in Saudi Arabian Public Organizations: An Exploratory Study,' IADIS International Conference Information Systems 2013, Lisbon, Portugal.

Al-Mashari, M. \& Al-Mudimigh, A. (2003). "ERP Implementation: lessons from a Case Study," Information Technology \& People, 16, 21-33.

Al-Mudimigh, A. S. (2007). "The Role and Impact of Business Process Management in Enterprise Systems Implementation," Business Process Management Journal, 13, 866-874.

Al-Mudimigh, A. S., Ullah, Z. \& Alsubaie, T. A. (2011). "A Framework for Portal Implementation: A Case for Saudi Organizations," International Journal of Information Management, 31, 38-43.

Al-Mudimigh, A., Zairi, M. \& Al-Mashari, M. (2001). "ERP Software Implementation: An Integrative Framework," European Journal of Information Systems, 10, 216-226.

Al-Shamlan, H. M. \& Al-Mudimigh, A. S. (2011). "The Chang Management Strategies and Processes for Successful ERP Implementation: A Case Study of MADAR," International Journal of Computer Science, 8, 431-435.

Alshitri, K. I. (2008). Quality Management Implementation in IS/IT Departments in Saudi Arabian Private Organizations, University of East Anglia.

Al-Turki, U. M. (2011). "An Exploratory Study of ERP Implementation in Saudi Arabia," Production Planning and Control, 22, 403-413.

Anderson, J. C. \& Rungtusanatham, M. (1994). "A Theory of Quality Management Underlying the Deming Management Method," Academy of Management Review, 19, 472-509.

Baccarini, D., Salm, G. \& Love, P. E. D. (2004). "Management of Risks in Information Technology Projects," Industrial Management \& Data Systems, 104, 286-295.
Belassi, W. \& Tukel, O. I. (1996). "A New Framework for Determining Critical Success/Failure Factors in Projects," International Journal of Project Management, 14, 141-151.

Benner, M. J. \& Tushman, M. (2002). "Process Management and Technological Innovation: A Longitudinal Study of the Photography and Paint Industries," Administrative Science Quarterly, 47, 676707.

Bhatti, T. R. (2005). "Critical Success Factors for the Implementation of Enterprise Resource Planning (ERP): Empirical Validation," The Second International Conference on Innovation in Information Technology (IIT'05), 1-10.

Bourne, L. \& Walker, D. H. T. (2008). "Project Relationship Management and the Stakeholder Circle ${ }^{\mathrm{TM}}, "$ International Journal of Managing Projects in Business, 1, 125130.

Chevers, D. A. \& Duggan, E. (2012). "A Jamaican Study of the Contribution of Process, People and Perception to Information Systems Quality and Success," The Electronic Journal of Information Systems in Developing Countries, 55.

Crawford, L. (2005). "Senior Management Perceptions of Project Management Competence," International Journal of Project Management, 23, 7-16.

Dezdar, S. \& Ainin, S. (2012). "Examining Successful ERP Projects in Middle-East and South-East Asia," American Journal of Scientific Research, 13-25.

EFQM-Multiproject (2010). EFQM Framework Mutiproject Management.

Esteves, J. \& Pastor, J. (2001). "Analysis of Critical Success Factors Relevance along SAP Implementation Phases," Proceedings of the Seventh Americas Conference on Information Systems, 1019-1025.

Finney, S. \& Corbett, M. (2007). "ERP Implementation: A Compilation and Analysis of Critical Success Factors," 
Business Process Management Journal, 13, 329-347.

Fortune, J. \& White, D. (2006). "Framing of Project Critical Success Factors by a Systems Model," International Journal of Project Management, 24, 53-65.

Gauld, R. (2007). "Public Sector Information System Project Failures: Lessons from a New Zealand Hospital Organization," Government Information Quarterly, 24, 102-114.

Gunasekaran, S. \& Garets, D. E. (2003). "Business Value of IT: The Strategic Planning Process," Journal of Healthcare Information Management: JHIM, 17, 31.

Gupta, A. (2000). "Enterprise Resource Planning: The Emerging Organizational Value Systems," Industrial Management \& Data Systems, 100, 114-118.

Heeks, R. (2002). "Information Systems and Developing Countries: Failure, Success, and Local Improvisations," The Information Society, 18, 101-112.

Holland, C. R. \& Light, B. (1999). "A Critical Success Factors Model for ERP Implementation," Software, IEEE, 16, 30-36.

Hong, E. K. (2009). "Information Technology Strategic Planning," IT Professional, 11, 8-15.

Hussein, R., Abdul Karim, N. S., Mohamed, N. \& Ahlan, A. R. (2007). "The Influence of Organizational Factors on Information Systems Success in E-Government Agencies in Malaysia," The Electronic Journal of Information Systems in Developing Countries, 29.

ISO9000 (2000). ISO 9000: 'Quality Management Systems - Fundamentals and Vocabulary,' International Organization for Standardization.

Jiang, J. J., Klein, G. \& Balloun, J. (1996). 'Ranking of System Implementation Success Factors,' Project Management Journal, 27, 49-53.
Kansal, V. (2007). Systemic Analysis for Inter-Relation of Identified Critical Success Factors in Enterprise Systems Projects, Contemporary Management Research, 3.

Kemppainen, J., Tedre, M., Parviainen, P. \& Sutinen, E. (2012). "Risk Identification Tool for ICT in International Development CoOperation Projects," The Electronic Journal of Information Systems in Developing Countries, 55.

Kumar, V., Maheshwari, B. \& Kumar, U. (2002). "ERP Systems Implementation: Best Practices in Canadian Government Organizations," Government Information Quarterly, 19, 147-172.

Mandal, P. \& Gunasekaran, A. (2003). "Issues in Implementing ERP: A Case Study," European Journal of Operational Research, 146, 274-283.

Morris, P. W. G., Jamieson, A. \& Shepherd, M. M. (2006). "Research Updating the APM Body of Knowledge 4th Edition," International Journal of Project Management, 24, 461-473.

Murray, M. \& Coffin, G. (2001). "A Case Study Analysis of Factors for Success in ERP System Implementations," Proceedings of the Seventh Americas Conference on Information Systems, 1012-1018.

Nah, F. F. H., Islam, Z. \& Tan, M. (2007). "Empirical Assessment of Factors Influencing Success of Enterprise Resource Planning Implementations," Journal of Database Management (JDM), 18, 26-50.

Nah, F. F. H., Zuckweiler, K. M. \& Lau, J. L. S. (2003). "ERP Implementation: Chief Information Officers' Perceptions of Critical Success Factors," International Journal of Human-Computer Interaction, 16, 5-22.

Ngai, E. W. T., Law, C. C. H. \& Wat, F. K. T. (2008). "Examining the Critical Success Factors in the Adoption of Enterprise Resource Planning," Computers in Industry, 59, 548-564.

Pinto, J. K. \& Mantel Jr, S. J. (1990). "The Causes of Project Failure," Engineering 
Management, IEEE Transactions On, 37, 269-276.

PMI (2004). A Guide to the Project Management Body of Knowledge: PMBOK® Guide, 4th Ed:: Project Management Institute.

Robey, D., Ross, J. W. \& Boudreau, M. C. (2002). "Learning to Implement Enterprise Systems: An Exploratory Study of the Dialectics of Change," Journal of Management Information Systems, 19, 1746.

Rosario, J. G. (2000). 'On the Leading Edge: Critical Success Factors in ERP Implementation Projects,' Business World, 17, 15-29.

Ross, J. W. (1999). "Surprising Facts about Implementing ERP," IT Professional, 1, 6568.

Shanks, G. G., Parr, A. N., Hu, B., Corbitt, B. J., Thanasankit, T. \& Seddon, P. (2000). "Differences in Critical Success Factors in ERP Systems Implementation in Australia and China: A Cultural Analysis," Proceedings of the 8th European Conference on Information Systems, Citeseer, 537-544.

Shenhar, A. J. \& Dvir, D. (1996). "Toward a Typological Theory of Project Management," Research Policy, 25, 607632.

Somers, T. M. \& Nelson, K. G. (2004). "A Taxonomy of Players and Activities across the ERP Project Life Cycle," Information \& Management, 41, 257-278.

Sumner, M. (1999). "Critical Success Factors in Enterprise Wide Information Management Systems Projects," Proceedings of the 1999 ACM SIGCPR Conference on Computer Personnel Research, ACM, 297-303.

Tukel, O. I. \& Rom, W. O. (2001). "An Empirical Investigation of Project Evaluation Criteria," International Journal of Operations \& Production Management, 21, 400-416.
White, D. \& Fortune, J. (2002). "Current Practice in Project Management-An Empirical Study," International Journal of Project Management, 20, 1-11.

Young, R. \& Jordan, E. (2008). "Top Management Support: Mantra or Necessity?," International Journal of Project Management, 26, 713-725.

Zhang, L., Lee, M. K. O., Zhang, Z. \& Banerjee, P. (2003). "Critical Success Factors of Enterprise Resource Planning Systems Implementation Success in China," System Sciences, 2003. Proceedings of the 36th Annual Hawaii International Conference On, IEEE, $10 \mathrm{Pp}$. 